\title{
WWR OPTIMIZATION For VENTILATION AND ENVIRONMENTAL NOISE CONTROL OF Tropical DWELLING
}

\section{Optimasi WWR Untuk PenghawaAn Dan Pengendalian Kebisingan LingKungan PADA HUNIAN TROPIS}

\author{
FX Teddy Badai Samodra ${ }^{1^{*}}$ \\ Departemen Arsitektur, Fakultas Arsitektur, Desain, dan Perencanaan, Institut Teknologi Sepuluh Nopember ${ }^{1^{*}}$ \\ fxteddybs@arch.its.ac.id; fxteddybs@gmail.com
}

\begin{abstract}
In an urban environment, heat and noise are the most important factors affecting the environment in buildings. This study optimizes the WWR (Window to Wall Ratio) as a compromise of the ventilation design and noise control for the Javanese architecture which is the case study of Eco-tropical built environment. The need for openings area has a contradictory behavior between providing the maximum aperture requirements to accelerate the wind flow and the minimum aperture area to reduce environmental noise. The location of this study is in the lowland (Surabaya, 0-50 m above mean sea level) and in the highland (Malang, 440-667 $\mathrm{m}$ above mean sea level) as the representatives of the tropical environment. Both cities were chosen because of their cultural and architectural similarities. The results of this study indicate noise propagation distance and vector wind as the determining factor to the WWR. Furthermore, the WWR range of integration of ventilation design needs and noise control are for lowland / daytime is 0.13-100\% (survey standard), 0.13-5.24\% (WHO standard); for lowland / night is 0-100\% (survey standard) and 0-3.24\% (WHO standard). Meanwhile, for highland/daytime, the requirement is $0.24-100 \%$ (survey standard) and 0.24-70.48\% (WHO standard); and for highland / night is $0-100 \%$ (for both WHO standard and survey criteria).
\end{abstract}

Keywords: noise control, ventilation, tropical dwelling, warm humid climate

\section{PENGANTAR}

Standar lingkungan dalam bangunan menentukan kondisi lingkungan yang berbeda, seperti termal, kualitas udara dalam ruangan, aural, dan visual (Huang et al, 2012). Dalam lingkungan perkotaan, termal dan kebisingan merupakan factor utama yang secara bersamaan mempengaruhi lingkungan dalam bangunan (Lai et al, 2009). Di sini, WWR (Window to Wall Ratio) merupakan aspek penting dalam pembahasan mengenai pengendalian kebisinginan (De Salis, at al, 2002).

Indonesia adalah sebuah daerah "cincin api". Hal itu terbukti dengan banyaknya gunung berapi yang mempengaruhi pola topografi yang terdiri atas dataran rendah dan dataran tinggi. Perbedaan ketinggian geografis sebagai representasi lingkungan tropis lembab tidak hanya menyebabkan variasi iklim dan lingkungan yang berpengaruh pada upaya perbaikan termal akibat perbedaan lingkungan, tetapi juga mempengaruhi variasi pertumbuhan kota. Hal ini terjadi karena biasanya kota di dataran rendah (lowland) tumbuh lebih cepat daripada kota di dataran tinggi (highland). Kondisi tersebut memiliki konsekuensi tidak hanya terhadap variasi penyebaran kebisingan dari luar ke dalam bangunan, tetapi juga adaptasi penghuni dan rancangan arsitekturalnya (Samodra, 2017). 
Di lingkungan tropis perkotaan, material dan WWR menjadi elemen selubung bangunan yang memegang peranan yang penting. Dengan perilaku yang bertentangan antara merancang penghawaan dan mengendalikan kebisingan, maka penelitian ini melakukan studi optimasi WWR sebagai integrasi solusi untuk kedua isu tersebut.

\section{METODE}

Penelitian ini memaparkan ide perbaikan lingkungan termal dan kebisingan bangunan dengan menelaah optimasi dan pengendalian terpadu pada kinerja termal dan kebisingan lingkungan. Secara detail, studi tentang kajian kompromi kebutuhan penghawaan dan pengendalian kebisingan dilakukan terhadap rumah Jawa sebagai studi kasus dari hunian tropis lembab. Seperti ditunjukkan oleh gambar 1, lokasi penelitian berada di dataran rendah (Surabaya, 0-50 m msl) dan di dataran tinggi (Malang, 440-667 m msl). Surabaya dan Malang merupakan dua kota terbesar di Provinsi Jawa Timur yang ditentukan sebagai lokasi penelitian karena memiliki kemiripan budaya dan arsitektur.

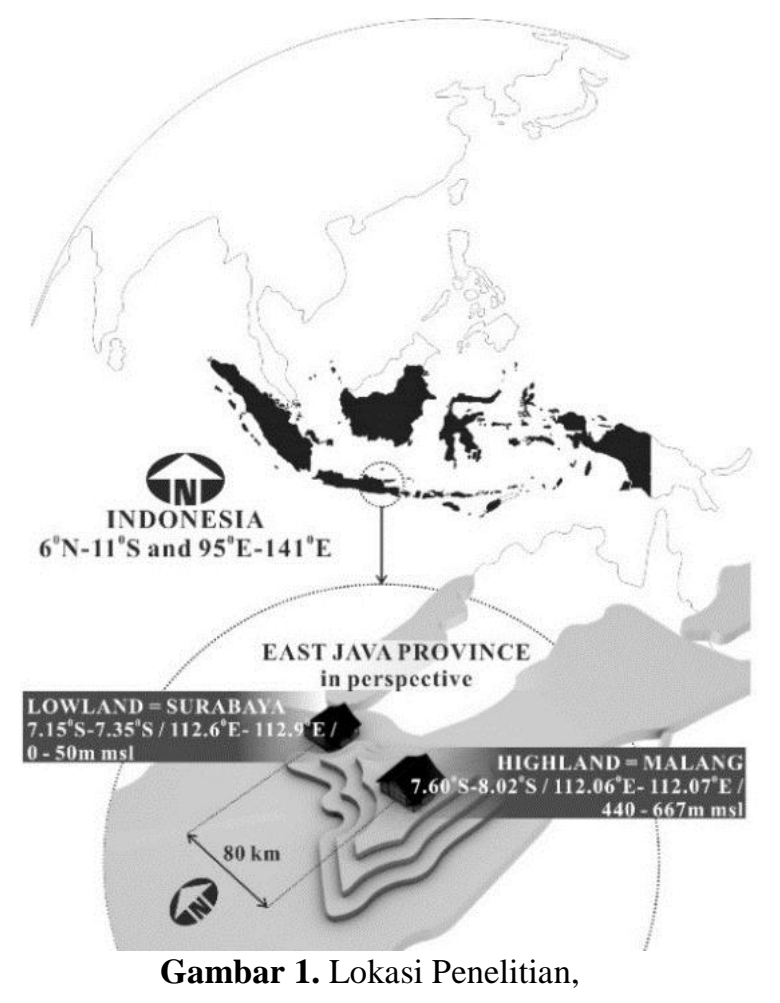

Seperti rumah tradisional di daerah tropis lembab pada umumnya, rumah tradisional Jawa (tipe kampung), pada awalnya dirancang untuk kondisi perdesaan yang masih terbuka. Namun, kondisi sekarang ini tumbuh di lingkungan padat perkotaan meskipun banyak yang masih mempertahankan ukuran dan material bangunan (lihat ilustrasi di lampiran kondisi lingkungan tropis). Baik untuk dataran rendah maupun dataran tinggi, hunian memiliki luas ukuran bangunan rata-rata $6 \times 7$ $\mathrm{m}^{2}$ (gambar 2). Bangunan tersebut memiliki pengunaan material bangunan yang bervariasi tergantung faktor lokasi dan waktu. Namun, secara umum didominasi oleh penggunaan dinding kayu (thermal dan acoustical properties: $\mathrm{U}$-value $=3.19 \mathrm{~W} / \mathrm{m}^{2} \mathrm{~K}$, Tlag $=0.3$ hour, $\mathrm{W}=24.8 \mathrm{~kg} / \mathrm{m}^{2}, \mathrm{t}=30 \mathrm{~mm}$, Transmission Loss in average: TLwood $=18$ $\mathrm{dB})$.

Berbeda dengan analisis material yang komplemen antara kebutuhan pengendalian panas dan kebisingan, kebutuhan luas bukaan memiliki perilaku yang kontradiktif; Penyelesaian arsitektural yang berlawanan antara kebutuhan menyediakan bukaan yang maksimum untuk aliran angin dan bukaan yang minimum untuk mengurangi kebisingan dari lingkungan. Kebutuhan luas bukaan ditentukan oleh WWR yang dihitung dari perbandingan luas bukaan (lobang) dan luas keseluruhan dinding parentalnya. Metode analisis WWR ini mempertimbangkan jarak sumber bunyi ke penerima sebagai faktor penting (gambar 3).

SNI 03-6386-2000 menetapkan kriteria desain kondisi akustik di dalam ruang hunian. Sementara, Keputusan Menteri Negara Lingkungan Hidup No. 48/MENLH/11/1996 merekomendasikan Tingkat Kebisinginan untuk kawasan perumahan dan permukiman adalah 55 dBA. Peraturan tersebut tidak memberikan rekomendasi yang membedakan standar untuk waktu siang atau malam hari. Samodra (2016) menunjukkan bahwa berdasarkan hasil survei, batas kebisingan lingkungan, baik dari sumber dalam maupun dari luar bangunan, untuk siang hari di dataran rendah ditetapkan $49.9 \mathrm{dBA}$ dan untuk dataran tinggi $47.8 \mathrm{dBA}$. Batas kebisingan malam hari untuk dataran rendah dan dataran tinggi, masing-masing $45.9 \mathrm{dBA}$ dan $40.0 \mathrm{dBA}$. 
Sementara itu, World Health Organization (WHO) merekomendasikan batas maksimum untuk kebisingan siang hari adalah $35.0 \mathrm{dBA}$ dan malam hari adalah $30.0 \mathrm{dBA}$ untuk hunian (Berglund et al, 2000). Kedua kriteria di atas menjadi pedoman dalam penentuan optimasi: Berdasarkan hasil survei atau standar survei dan berdasarkan rekomendasi atau standar WHO.

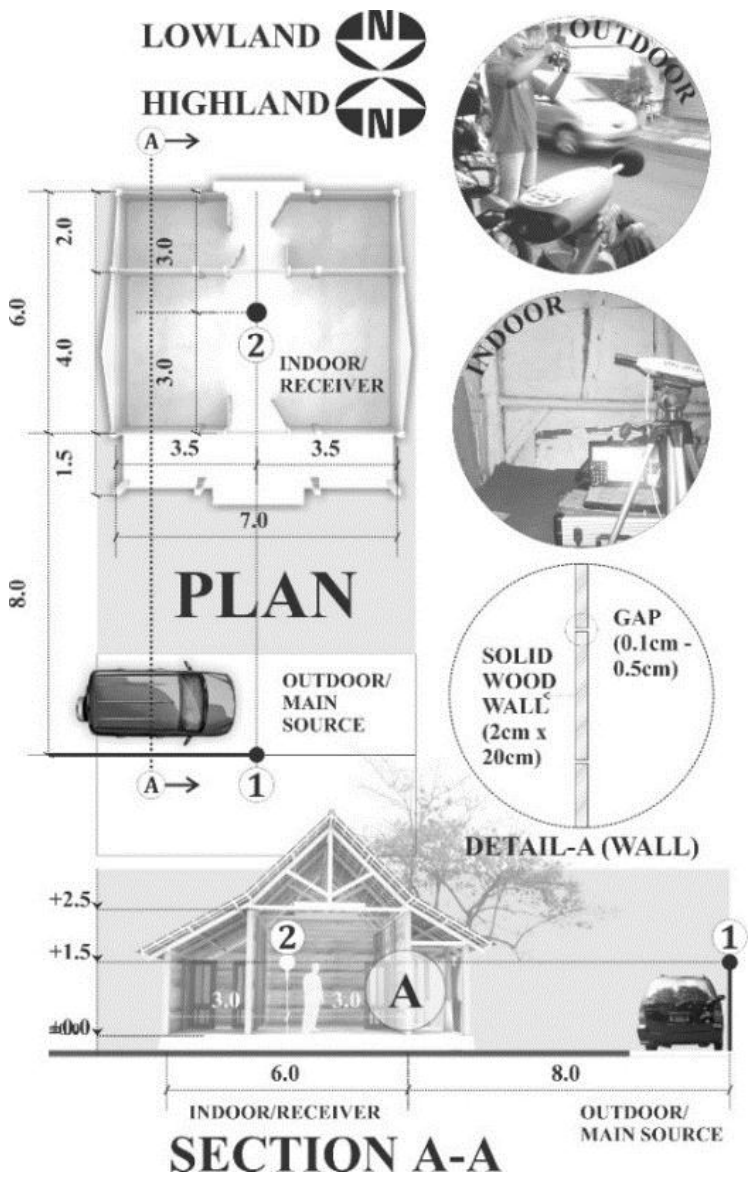

Gambar 2. Profil Bangunan,

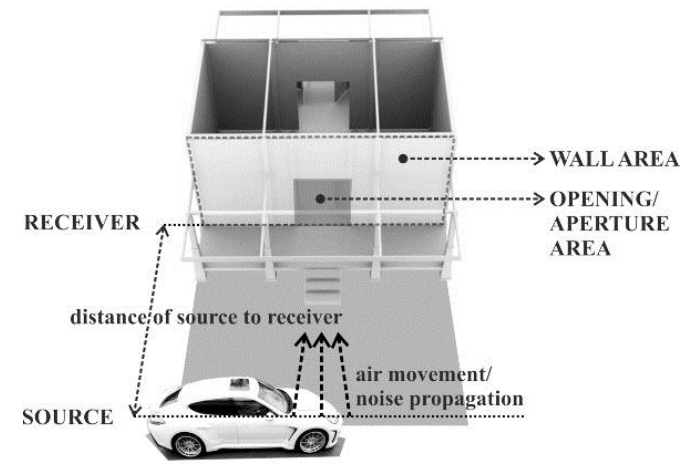

Gambar 3. Metode Analisis Windows to Wall Ratio (WWR),
Dalam penelitian ini, metode evaluasi matematik dilakukan untuk mencapai standar dari hasil survei dan WHO terkait integrasi kedua aspek, penghawaan dan kebisingan. Secara umum metode perhitungan dijelaskan berdasarkan langkah-langkah sebagai berikut.

1. Perhitungan minimum debit aliran angin (flow rate) yang diperlukan untuk penghawaan (persamaan 2).

2. Penentuan luas minimum bukaan dan WWR untuk penghawaan dengan pertimbangan pendinginan fisiologis untuk dataran rendah dan tinggi, untuk siang dan malam hari (persamaan 3).

3. Perhitungan efektivitas pengendalian bising (SRI index) yang mempertimbangkan koefisien serap bunyi dari material dan bukaan serta luasannya (persamaan 4).

4. Perhitungan luas bukaan maksimum untuk pengendalian bising dengan mempertimbangkan jarak kritis (minimum yang diperkenankan) sumber kebisinginan utama ke penerima bunyi.

\section{HASIL DAN PEMBAHASAN}

\subsection{VECTOR WIND DAN PROPAGASI KEBISINGAN}

Gambar 4. dan 5. menunjukkan vector wind dan hubungannya dengan kebisingan. Vector wind adalah komponen vektor dari kecepatan angin rata-rata $\mathrm{V}$ untuk sudut $\theta$ antara arah angin dan garis yang tegak lurus terhadap jalan melalui titik prediksi (Persamaan 1). Vector wind positif apabila searah dengan arah angin dan negatif dalam kondisi melawan arah angin. Untuk jarak pendek dari sumber kebisingan ke penerima, angin memiliki pengaruh yang kecil. Sejalan dengan hasil penelitian Tanaka dan Shiraishi (2008), modifikasi jarak dan Vector wind akan mempengaruhi tingkat kebisingan.

Baik untuk dataran rendah maupun dataran tinggi, nilai regresinya adalah 0,6 , itu berarti vector wind tidak memiliki pengaruh yang kuat untuk jarak eksisting rata-rata, $8 \mathrm{~m}$. Hal ini juga ditunjukkan oleh nilai vector wind sama dengan 0 tetapi masih memiliki tingkat tekanan bunyi yang tinggi. Mesipun demikian, nilai arah angin negatif dan nol tetap lebih 
rendah dari arah positif. Ini menunjukkan adanya pengaruh angin pada propagasi kebisingan meskipun dalam skala yang kecil. Menambahkan temuan Sakamoto (2015), untuk jarak yang dekat, kurang dari $15 \mathrm{~m}$, angin tidak memiliki pengaruh dalam persebaran kebisingan.

$\mathrm{Uvec}=\mathrm{V} \cos \theta$

di mana:

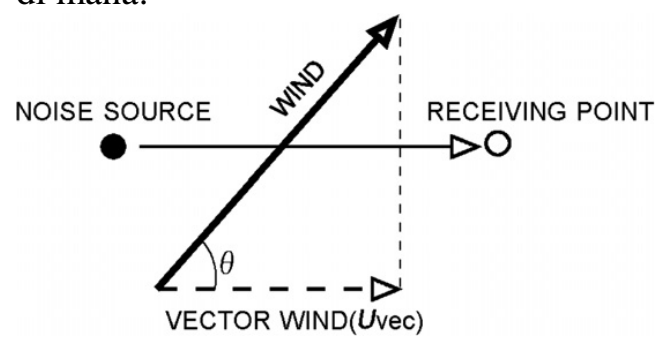

Sumber: Tanaka dan Shiraishi (2008)

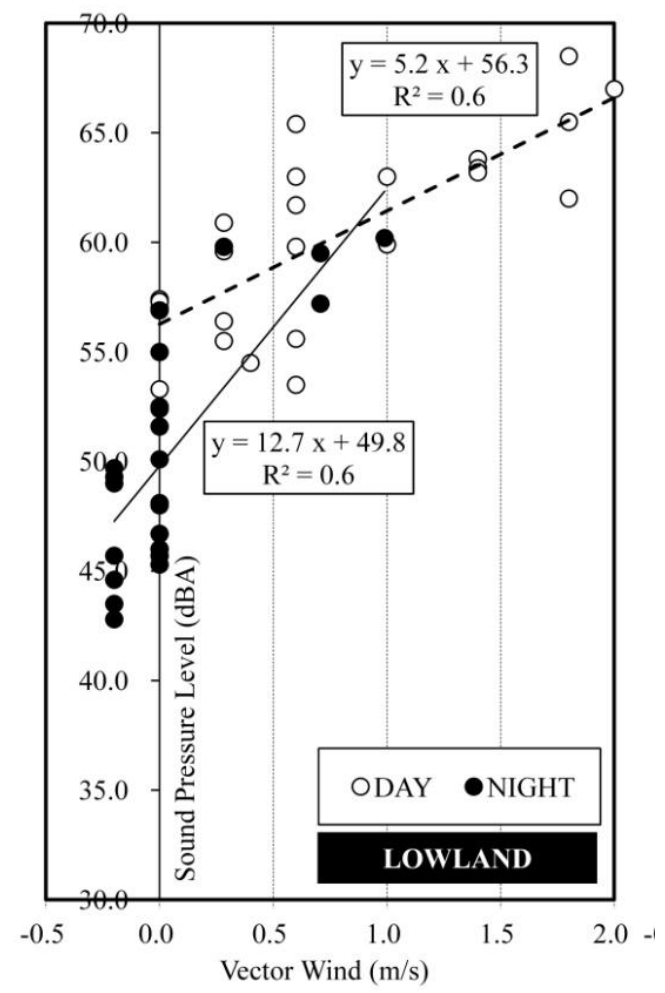

Day:06:00-18:00, Night:18:00-06:00

Gambar 4. Vector Wind dan Efek terhadap Propagasi Bising Dataran Rendah,

Sumber: Pengukuran Lapangan (April-Mei, 2014)

Lebih lanjut lagi, kondisi malam hari yang lebih rendah tingkat kebisingannya, di satu sisi merupakan sebuah keuntungan dari segi acuan atau kriteria yang lebih tinggi, tetapi di sisi lain faktor angin terlihat lebih rendah pengaruhnya. Beberapa hasil pengukuran dengan arah propagasi kebisingan sejajar (vector wind $=0$ ), memiliki nilai yang variatif diterima oleh bangunan. Kondisi tersebut ternyata lebih dominan pada kondisi malam hari. Hal yang dapat disimpulkan bahwa kecepatan angin di daerah tropis pada umumnya melemah pada malam hari, sehingga peran angin sebagai medium pembawa bunyi (airborne transfer) tidak cukup efektif bekerja.

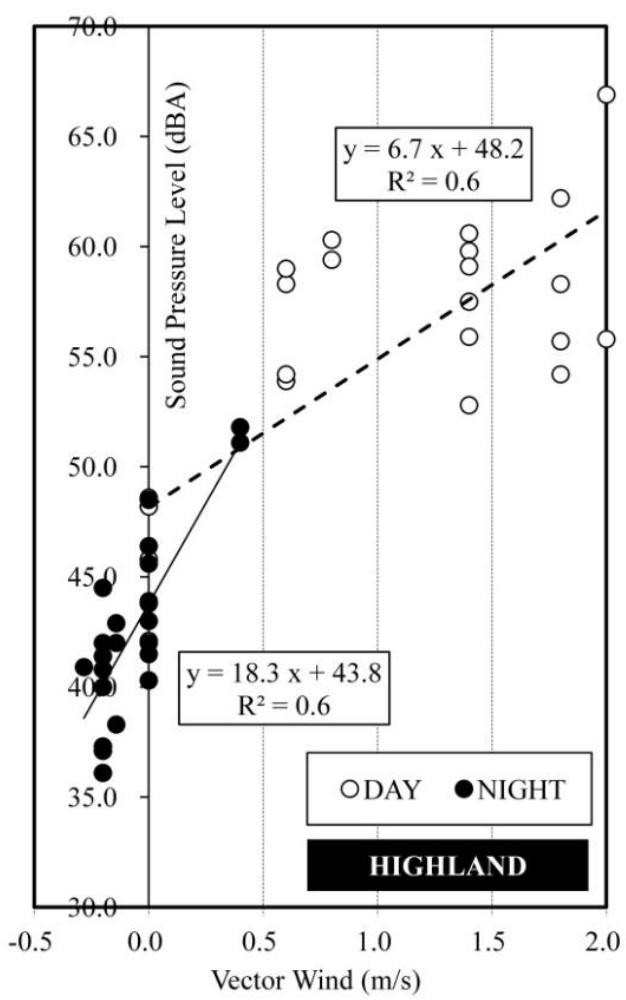

Day:06:00-18:00, Night:18:00-06:00

Gambar 5. Vector Wind dan Efek terhadap Propagasi Bising Dataran Tinggi,

Sumber: Pengukuran Lapangan (April-Mei, 2014)

Hasil dari evaluasi vector wind ini akan menjadi pertimbangan integrasi WWR. Jarak kurang dari $15 \mathrm{~m}$ seperti kondisi eksiting akan ditetapkan sebagai baseline untuk menentukan titik optimum pengendalian kebisingan dan penyediaan penghawaan untuk pendinginan pasif. Selanjutnya, kondisi bukaan terbuka penuh dan tertutup penuh akan merekomendasikan jarak spesifik untuk perbaikan termal dan kebisingan lingkungan. 


\subsection{INTEGRASI WWR}

Berdasarkan SNI 03-6572-2001 dan Keputusan Menteri Pekerjaan Umum No. 441/KPTS/1998, kebutuhan minimum penghawaan alami bangunan minimum 5\% dari luas lantai. Sementara, kebutuhan aliran angin menurut ANSI/ASHRAE Standard 552004, setiap penghuni membutuhkan 7.5 cubic feet per minute (CFM) dan bangunan membutuhkan 3 CFM setiap 100 square feet. Seperti diilustrasikan oleh persamaan 2, dengan rata-rata jumlah penghuni 5 orang, minimum aliran angin yang diperlukan untuk bangunan adalah $51.1 \mathrm{ft}^{3} / \mathrm{m}=0.024 \mathrm{~m}^{3} / \mathrm{s}$.

$$
\mathrm{Q}=(7.5 . \mathrm{Np})+(3 . \mathrm{A} / 100) \ldots \ldots \ldots \ldots \ldots . .
$$

Kecepatan angin minimum untuk pendinginan fisiologis berdasarkan penelitian sebelumnya adalah $1.5 \mathrm{~m} / \mathrm{s}$ untuk daerah dataran rendah dan $0.8 \mathrm{~m} / \mathrm{s}$ untuk dataran tinggi (Samodra, 2016). Kedua data kecepatan angin tersebut untuk kondisi siang hari (daytime). Sedangkan malam hari (night-time) tidak diperlukan pendinginan fisiologis karena memiliki temperatur yang lebih rendah. Dengan persamaan 3 dan $Q=0.024 \mathrm{~m}^{3} / \mathrm{s}$, luas minimum bukaan untuk penghawaan atau $\mathrm{A}_{\mathrm{A}}$ sama dengan $0.03 \mathrm{~m}^{2}$ dan $0.05 \mathrm{~m}^{2}$ masingmasing untuk dataran rendah dan dataran tinggi.

$$
\mathrm{Q}=\mathrm{E} \cdot \mathrm{A} \cdot \mathrm{A}
$$

Untuk efektivitas pengendalian kebisingan lingkungan, analisis SRI index dari material bangunan (dinding) dan bukaan perlu diterapkan dengan pertimbangan luas masingmasing permukaannya (persamaan 4).

$$
\begin{aligned}
& \mathrm{SRI}+\mathrm{A}= \\
& -10 \log \left[\frac{\mathrm{Aw} \cdot 10^{\left(\frac{-\mathrm{SRIw}}{10}\right)}+\mathrm{A}_{\mathrm{A}} \cdot 10^{\left(\frac{-\mathrm{SRIA}}{10}\right)}}{\left(\mathrm{Aw}+\mathrm{A}_{\mathrm{A}}\right)}\right]
\end{aligned}
$$

(opened aperture, $\mathrm{SRI}_{\mathrm{W}}=0$ ).

sumber: De Salis, at al (2002)

Tabel 1 merangkum hasil perhitungan optimasi WWR. Dalam variasi jarak, terdapat perbedaan kriteria untuk integrasi perbaikan termal dan penyebaran kebisingan. Karena kondisi temperatur yang lebih tinggi dibanding malam hari, penghawaan untuk pendinginan fisiologis hanya diperlukan ketika siang hari. Minimum WWR adalah $0.13 \%$ dan $0.24 \%$ masing-masing untuk dataran rendah dan dataran tinggi.

Seperti yang juga ditunjukkan oleh gambar 6 , untuk batas kebisingan berdasarkan survei, di semua lokasi dan waktu, tidak ada batas maksimum WWR untuk pengendalian kebisingan, diindikasikan dengan nilai WWR $=100 \%$. Hal ini menunjukkan bahwa rancangan bangunan cukup bebas dalam menyediakan bukaan yang terbuka lebar meskipun dengan jarak sumber bunyi yang dekat dengan penerima. Terdapat ketentuan di mana WWR harus 0\% (tidak diperkenankan adanya bukaan) dengan jarak yang sangat minimum. Hal ini jarang terjadi dalam kondisi nyata di lapangan, karena jarak sumber ke penerima bunyi dihasilkan tidak lebih dari 1 $\mathrm{m}$.

Dengan persyaratan yang lebih terbatas, toleransi kebisingan dari WHO merekomendasikan bahwa bangunan di daerah dataran tinggi tidak memiliki kriteria khusus seperti halnya untuk dataran rendah (gambar 7). Hal ini terjadi karena di dataran tinggi memiliki tingkat kebisingan yang lebih rendah. Rentang kriteria tersebut akan berbeda menurut standar, tempat, dan waktu.

Seperti pada hasil analisis sebelumnya, dalam integrasi pengendalian yang melibatkan WWR, faktor jarak dari sumber kebisingan juga dipertimbangkan dalam penelitian ini, khususnya terkait dengan pengaruh terhadap bukaan. Fakor jarak ini ini ditentukan sebagai jarak kritis. Untuk bukaan yang tertutup (WWR $=0 \%$ untuk pengendalian kebisingan), rekomendasi jarak minimum untuk menghindarkan kebisingan adalah $3.95 \mathrm{~m}$, $4.65 \mathrm{~m}, 1.56 \mathrm{~m}$, dan $0.91 \mathrm{~m}$ masing-masing untuk dataran rendah/siang hari, dataran rendah/malam hari, dataran tinggi/siang hari, dan dataran tinggi/malam hari. Sementara itu, jarak aman dengan pengunaan bukaan untuk WWR $100 \%$ adalah $22.1 \mathrm{~m}, 25.9 \mathrm{~m}, 8.8 \mathrm{~m}$, dan $5.15 \mathrm{~m}$, masing-masing untuk dataran rendah/siang hari, dataran rendah/malam hari, 
dataran tinggi/siang hari, dan dataran tinggi/malam hari.

Tabel 1. Hasil Optimasi Kebutuhan WWR untuk Penghawaan dan Pengendalian Kebisingan dalam Variasi Jarak Sumber ke Penerima Bunyi

\begin{tabular}{|c|c|c|c|c|c|}
\hline \multirow{3}{*}{$\begin{array}{l}\text { Location/ } \\
\text { Time }\end{array}$} & \multirow{3}{*}{$\begin{array}{l}\text { Distance } \\
(\mathrm{m})\end{array}$} & \multicolumn{4}{|c|}{ WWR Requirement } \\
\hline & & \multicolumn{2}{|c|}{ Field Study Limits } & \multicolumn{2}{|c|}{ WHO Standard } \\
\hline & & $\begin{array}{l}\text { Minimum for } \\
\text { Thermal } \\
\text { Improvement }\end{array}$ & $\begin{array}{l}\text { Maximum for } \\
\text { Noise } \\
\text { Improvement }\end{array}$ & $\begin{array}{l}\text { Minimum for } \\
\text { Thermal } \\
\text { Improvement }\end{array}$ & $\begin{array}{l}\text { Maximum for } \\
\text { Noise } \\
\text { Improvement }\end{array}$ \\
\hline \multirow{5}{*}{$\begin{array}{l}\text { Lowland/ } \\
\text { Daytime }\end{array}$} & $8^{*}$ & $0.13 \%$ & $100 \%$ & $0.13 \%$ & $5.24 \%$ \\
\hline & 0.72 & $0.13 \%$ & $0 \% * *$ & - & - \\
\hline & 4.02 & $0.13 \%$ & $100 \% * * *$ & - & - \\
\hline & 3.95 & - & - & $0.13 \%$ & $0 \% * *$ \\
\hline & 22.1 & - & - & $0.13 \%$ & $100 \% * * *$ \\
\hline \multirow{5}{*}{$\begin{array}{l}\text { Lowland/ } \\
\text { Night-time }\end{array}$} & 8* & $0 \% * * * *$ & $100 \%$ & $0 \% * * * *$ & $3.24 \%$ \\
\hline & 0.75 & $0 \%$ & $0 \% * *$ & - & - \\
\hline & 4.21 & $0 \%$ & $100 \% * * *$ & - & - \\
\hline & 4.65 & - & - & $0 \%$ & $0 \% * *$ \\
\hline & 25.9 & - & - & $0 \%$ & $100 \% * * *$ \\
\hline \multirow{5}{*}{$\begin{array}{l}\text { Highland/ } \\
\text { Daytime }\end{array}$} & $8^{*}$ & $0.24 \%$ & $100 \%$ & $0.24 \%$ & $70.48 \% * *$ \\
\hline & 0.36 & $0.24 \%$ & $0 \% * *$ & - & - \\
\hline & 2.02 & $0.24 \%$ & $100 \% * * *$ & - & - \\
\hline & 1.56 & - & - & $0.24 \%$ & $0 \% * *$ \\
\hline & 8.8 & - & - & $0.24 \%$ & $100 \% * * *$ \\
\hline \multirow{5}{*}{$\begin{array}{l}\text { Highland/ } \\
\text { Night-time }\end{array}$} & $8 *$ & $0 \% * * * *$ & $100 \%$ & $0 \% * * * *$ & $100 \% * *$ \\
\hline & 0.29 & $0 \%$ & $0 \% * *$ & - & - \\
\hline & 1.63 & $0 \%$ & $100 \% * * *$ & - & - \\
\hline & 0.91 & - & - & $0 \%$ & $0 \% * *$ \\
\hline & 5.15 & - & - & $0 \%$ & $100 \% * * *$ \\
\hline
\end{tabular}

*) existing in average distance

**) no aperture (totally closed) requirement by minimum distance

***) totally opened aperture requirement by minimum distance

****) no need aperture for night-time

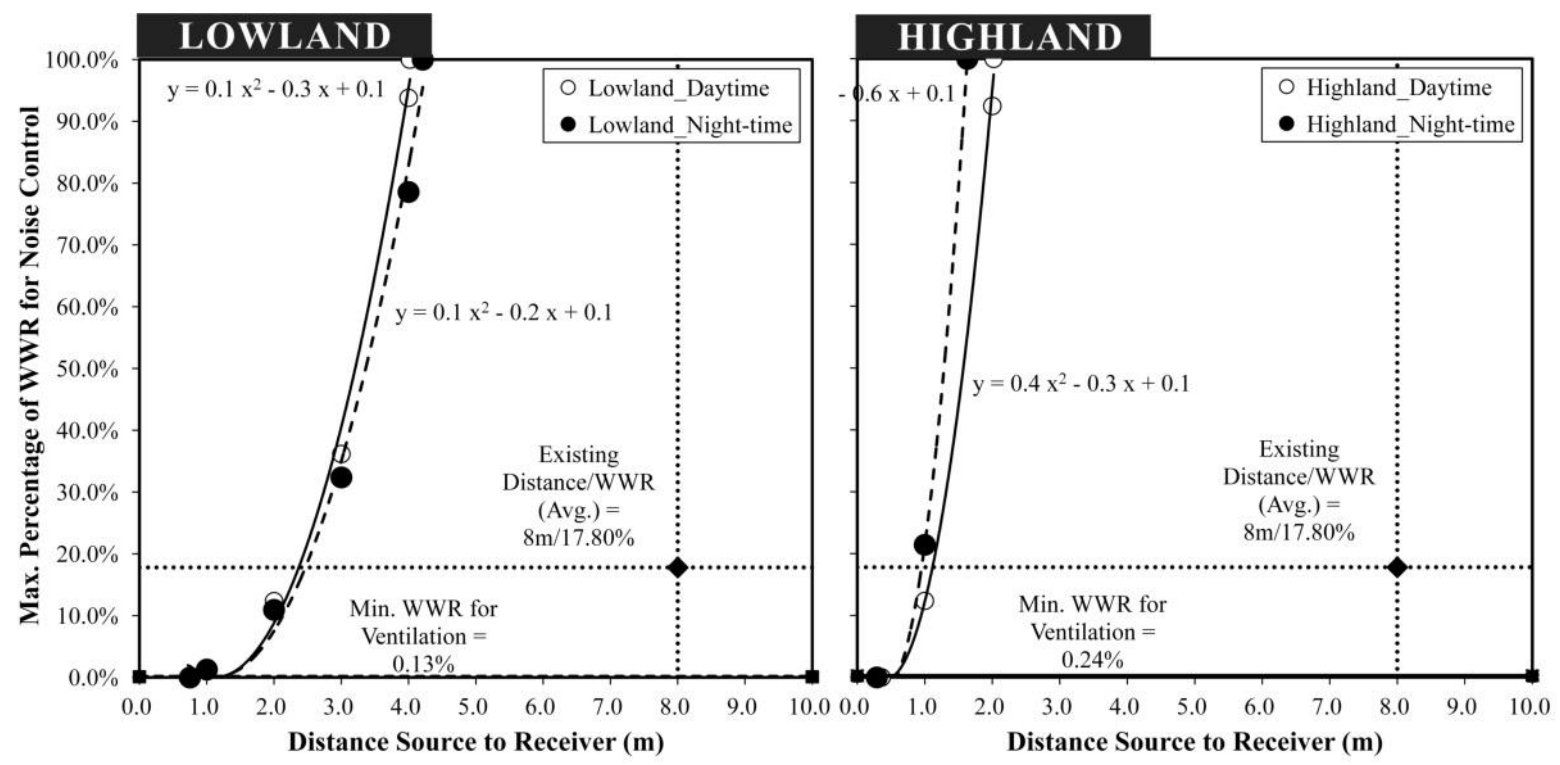

Gambar 6. Optimasi WWR untuk Penghawaan (Pendinginan Fisiologis) dan Pengendalian Kebisingan Berdasarkan Batas Kebisingan Hasil Survei. 


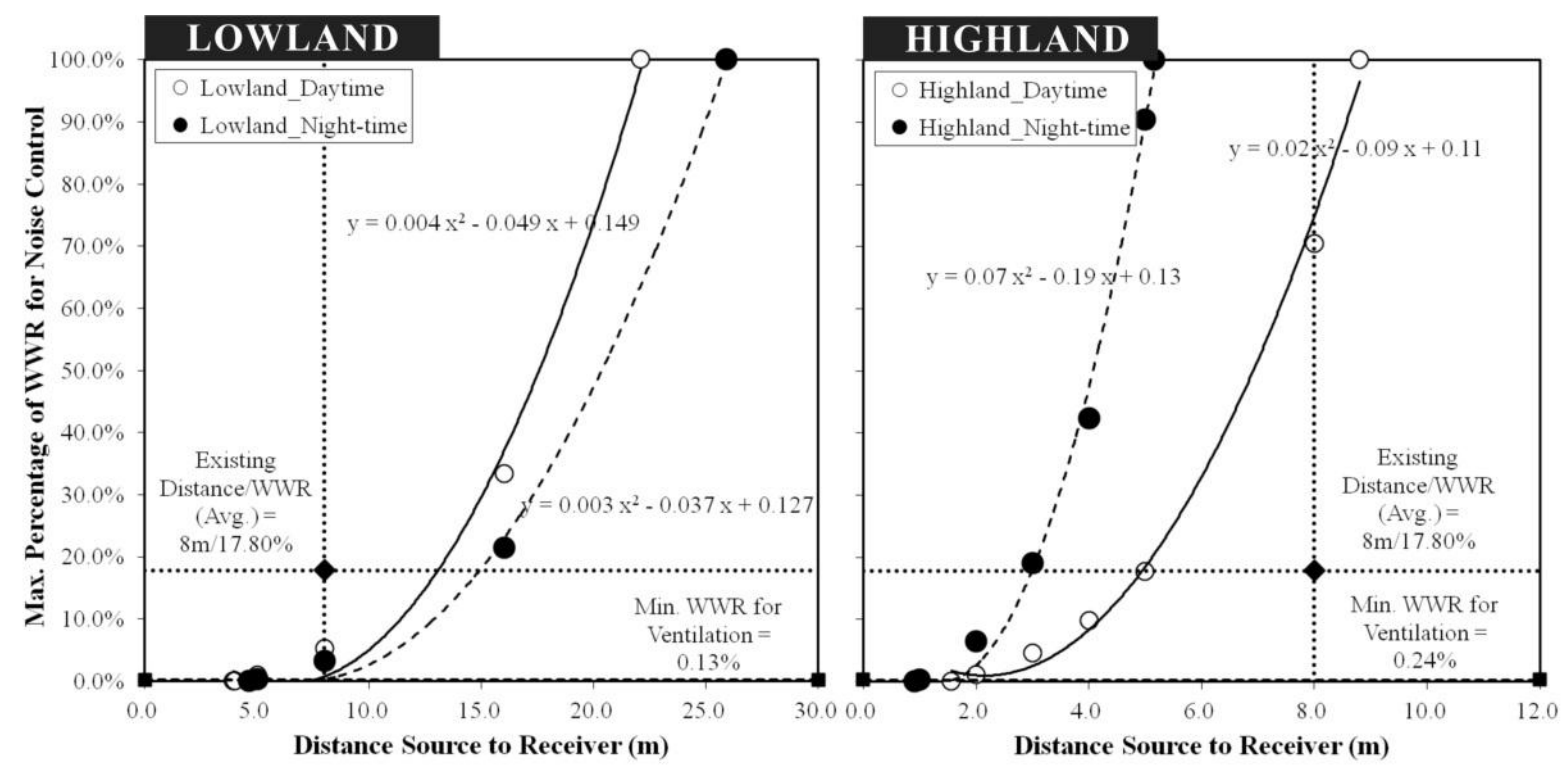

Gambar 7. Optimasi WWR untuk Penghawaan (Pendinginan Fisiologis) dan Pengendalian Kebisingan Berdasarkan Batas Kebisingan WHO.

\subsection{INTEGRASI STRATEGI PENGENDALIAN LINGKUNGAN}

Terkait pengembangan rancangan pengendalian terintegrasi dalam konteks perkotaan. WWR sebagai elemen konektor lingkungan luar dan dalam bangunan adalah kunci pokok dalam menyelesaikan masalah lingkungan tersebut. Seperti diilustrasikan oleh gambar 8., dalam skala lebih luas, gagasan interkoneksi antara lingkungan luar dan dalam bangunan mengarahkan pada tahap-tahap sebagai berikut:

1. Skala tapak: Selain jarak dari sumber ke penerima bunyi (kebisingan), rekomendasi untuk menghalang pada dasarnya cukup efektif sebagai elemen yang berdiri sendiri, tetapi memiliki konsekuensi pada pergerakan angin untuk penghawaan dan aspek arsitektural seperti view dan image bangunan. Strategi pengendalian ini juga dapat terintegrasi dengan usulan WWR.

2. Skala bangunan: Organisasi ruang adalah strategi pasif dalam memetakan ruangruang yang harus terproteksi tinggi atau rendah terharap bising atau paparan angin. Zoning, menjadi metode umum rancangan yang menempatkan sebuah ruang khusus menjauhi sumber (kembali ke faktor jarak sebagai aspek penentu). Di sini, pertimbangan arah angin menjadi kritis juga. Lebih lanjut lagi, faktor bukaan yang direpresentasikan dalam WWR kembali menjadi solusi.

3. Skala detail: Konteks rancangan ini memiliki kemungkinan sebagai alternatif terakhir. Meskipun demikian solusi yang diberikan akan adaptif. Material dan WWR dalam skala ini merupakan strategi integratif. Apabila sebuah ruang karena pertimbangan arsitektural atau nonarsitektural harus ditempatkan pada area yang harus dekat dengan sumber utama kebisingan, maka material dan WWR akan bekerja efektif. Untuk itu, usulan WWR dalam penelitian ini cukup solutif menanggapi problem spesifik rancangan, khususnya hunian tropis. Pertimbangan konteks tempat, waktu, dan acuan standar juga sudah ditawarkan.

Skala penyelesaian termal dan kebisingan di atas selain dapat secara individu dirancang, integrasi antar skala memungkinkan ke depannya. Prioritas rancangan arsitektural tetap menjadi pertimbangan mutlak kopromi integrasi antar skala tersebut. 


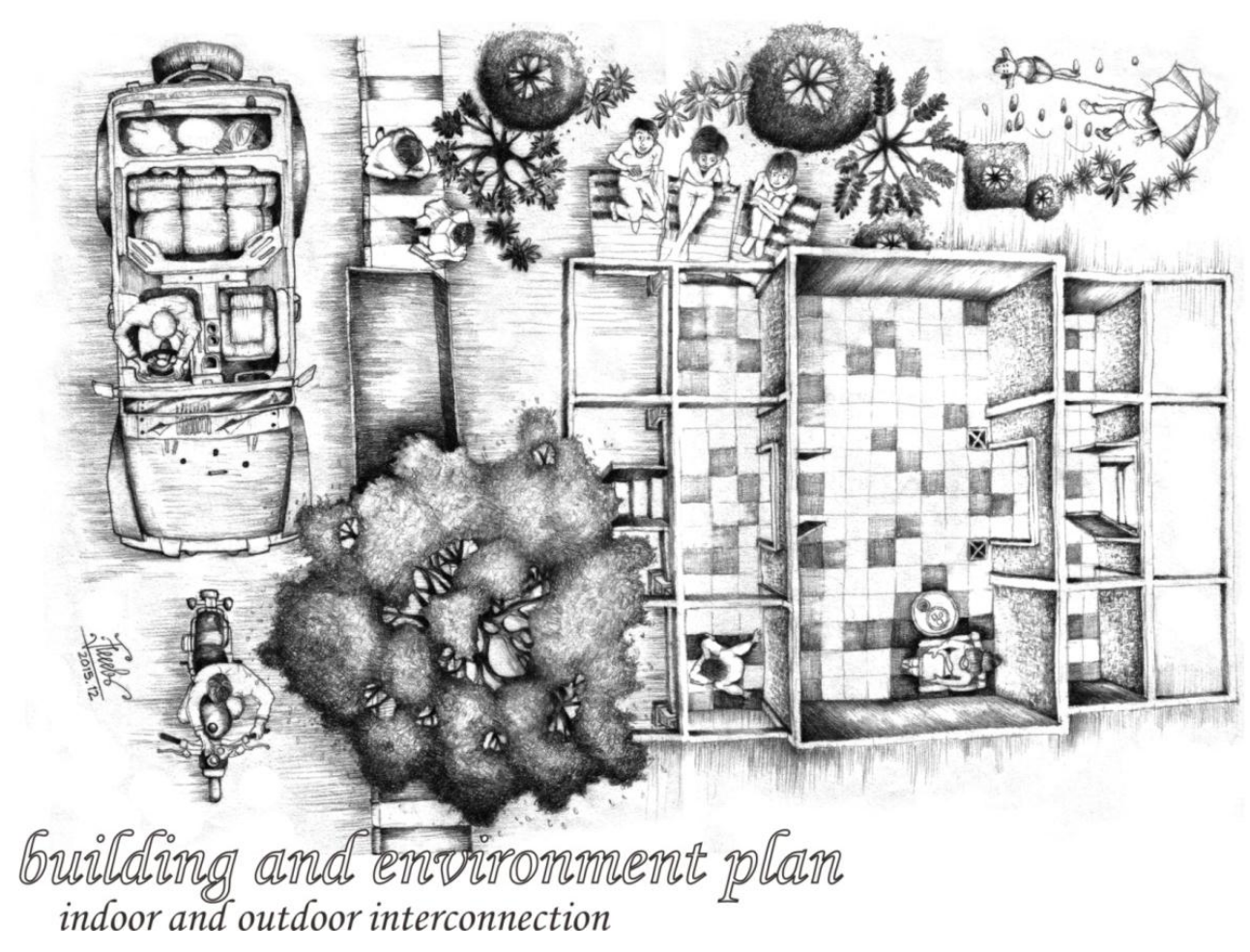

Gambar 8. Integrasi WWR, Penghalang kebisingan, dan Material dalam Koneksi Ruang Luar sebagai Sumber dan Bangunan dan Penghuni sebagai Penerima.

\section{KESIMPULAN}

Propagasi kebisingan akan sejalan dengan akselerasi angin untuk pendinginan pasif dalam perbaikan lingkungan termal. Dalam hal ini jarak dan vector wind menjadi faktor penting. Rancangan yang mengakomodasi datangnya angin daru sumber bising akan menentukan persentase WWR yang akan kontekstual menurut lokasi, waktu, dan kriteria yang dijadikan acuan.

Berdasarkan analisis di atas, kebutuhan WWR untuk pemenuhan kebutuhan penghawaan bangunan dan pengendalian penyebaran kebisingan, yaitu menurut kriteria hasil survei dan WHO, untuk dataran rendah siang hari memiliki nilai minimum yang sama untuk perbaikan lingkungan termal, tanpa ada batasan maksimum untuk kebisingan. Sementara itu dengan tidak ada batasan juga, kondisi malam hari memiliki toleransi yang mutlak besar menurut kriteria hasil survei (tanpa batas minimum atau maksimum). Namun, dengan standar WHO, hasilnya merekomendasikan terbatas $3.24 \%$ untuk mencegah masuknya bunyi yang tidak dikehendaki ke dalam bangunan.

Dengan ketentuan yang sama dengan dataran rendah kondisi siang hari menurut kriteria survei dan WHO, kondisi di dataran tinggi membutuhkan kecepatan angin yang lebih renda. Hal ini memiliki konsekuensi WWR yang berbeda, yaitu $0.24 \%$ untuk menyediakan kecepatan angin yang lebih rendah (WWR di sini dihasilkan lebih besar). Sementara itu, kondisi malam memiliki persyaratan yang sama, tanpa ada rekomendasi untuk perbaikan termal karena kondisinya yang nyaman, tetapi terdapat batas maksimum $3.24 \%$ kebisingan untuk semua kriteria. Semua kriteria di atas untuk kondisi jarak rata-rata eksisting $(8 \mathrm{~m})$.

Penelitian ini hanya salah satu dari sekian banyak gagasan penyelesaikan pemasalahan arsitektural di lingkungan perkotaan tropis lembab. Beberapa strategi sebagai rekomendasi untuk penelitian selanjutnya dalam kaitannya dengan integrasi rancangan untuk penghawaan dan kebisingan adalah 
analisis material bangunan dan analisis tapak untuk penghalang lingkungan (site barrier, seperti dalam gambar 8). Namun, rujukan tersebut akan terintegrasi dengan rancangan WWR hasil penelitian ini.

\section{SIMBOL}

\begin{tabular}{|c|c|c|}
\hline A & $=$ Floor area & {$\left[\mathrm{m}^{2}\right]$} \\
\hline $\mathrm{A}_{\mathrm{A}}$ & $\begin{array}{l}=\text { Free area of inlet } \\
\text { openings }\end{array}$ & {$\left[\mathrm{m}^{2}\right]$} \\
\hline $\begin{array}{l}\mathrm{A}_{\mathrm{w}} \\
\mathrm{E}\end{array}$ & $\begin{array}{l}=\text { Area of Wall } \\
=\text { effectiveness of } \\
\text { openings }(0.5-0.6 \text { for } \\
\text { perpendicular winds })\end{array}$ & {$\left[\mathrm{m}^{2}\right]$} \\
\hline $\mathrm{Np}$ & $=$ Number of people & \\
\hline Q & $=$ Air flow & {$\left[\mathrm{CFM} ; \mathrm{m}^{3} / \mathrm{s}\right]$} \\
\hline $\mathrm{SRI}_{\mathrm{W}}$ & $\begin{array}{l}=\text { Sound Reduction } \\
\text { Index }=\text { Transmission } \\
\text { Loss for Wall }\end{array}$ & {$[\mathrm{dBA}]$} \\
\hline $\mathrm{SRI}_{\mathrm{A}}$ & $\begin{array}{l}=\text { Sound Reduction } \\
\text { Index }=\text { Transmission } \\
\text { Loss for openings }\end{array}$ & {$[\mathrm{dBA}]$} \\
\hline $\mathrm{t}$ & $\begin{array}{l}=\text { Thickness of } \\
\text { material }\end{array}$ & {$[\mathrm{m}, \mathrm{mm}]$} \\
\hline Tlag & $=$ Time lag & [hours] \\
\hline value & $\begin{array}{l}=\text { Thermal } \\
\text { transmittance }\end{array}$ & {$\left[\mathrm{W} / \mathrm{m}^{2} \mathrm{~K}\right]$} \\
\hline $\begin{array}{l}\text { Uvec } \\
\text { V }\end{array}$ & $\begin{array}{l}=\text { Vector Wind } \\
=\text { Wind velocity }\end{array}$ & $\begin{array}{l}{[\mathrm{m} / \mathrm{s}]} \\
{[\mathrm{m} / \mathrm{s}]}\end{array}$ \\
\hline W & $=$ Weight of material & {$\left[\mathrm{kg} / \mathrm{m}^{2}\right]$} \\
\hline WWR & $\begin{array}{l}=\text { Window to Wall } \\
\text { Ratio }\end{array}$ & {$[\%]$} \\
\hline
\end{tabular}

\section{REFERENSI}

\section{ANSI/ASHRAE Standard 55-2004 (Supersedes ANSI/ASHRAE Standard 55-1992): Standard for Thermal Environmental Conditions for Human Occupancy.}

Berglund, B., Lindvall T., Schwela D., Goh, K.T. (2000). Guidelines for Community Noise. Geneva: World Health Organization (WHO).
De Salis, M.H.F., Oldham, D.J., Sharples, S. (2002). Noise Control Strategies for Naturally Ventilated Buildings. Building and Environment, 37, 471-484.

Huang, L., Zhu, Y., Ouyang Q., Cao, B. (2012). A Study on The Effects of Thermal, Luminous, and Acoustic Environments on Indoor Environmental Comfort in Offices. Building and Environment, 49, 304-309.

Keputusan Menteri Negara Lingkungan Hidup No. 48/MENLH/11/1996: Baku Tingkat Kebisingan.

Keputusan Menteri Pekerjaan Umum No. 441/KPTS/1998: Persyaratan Teknis Bangunan.

Lai, A.C.K., Mui, K.W., Wong, L.T., Law, L.Y. (2009). An Evaluation Model for Indoor Environmental Quality (IEQ) Acceptance in Residential Buildings. Energy and Buildings, 41, 930-936.

Sakamoto, S. (2015). Road traffic noise prediction model "ASJ RTN-Model 2013": Report of the research committee on road traffic noise, Acoustical Science and Technology, 36(2), 49-108.

Samodra, F.X.T.B. (2016). Proposal for Thermal and Noise Environment Improvement of The Traditional House in Indonesia. Busan: Thesis for the degree of Doctor of Philosophy, Pusan National University.

Samodra, F.X.T.B. (2017). Analysis of Resilient Design by Thermoacoustic Adaptation of Tropical Urban Model. Journal of Architecture and Urbanism, 41(4), 305-315.

SNI 03-6386-2000: Spesifikasi Tingkat Bunyi dan Waktu Dengung dalam Bangunan Gedung dan Perumahan (Kriteria Desain yang Direkomendasikan).

SNI 03-6572-2001: Tata Cara Perancangan Sistem Ventilasi dan Pengkondisian Udara pada Bangunan Gedung.

Tanaka, S, Shiraishi, B. (2008). Wind Effects on Noise Propagation for Complicated Geographical and Road Configurations. Applied Acoustics, 69, 1038-1043. 


\section{LAMPIRAN}

Kondisi Lingkungan Tropis

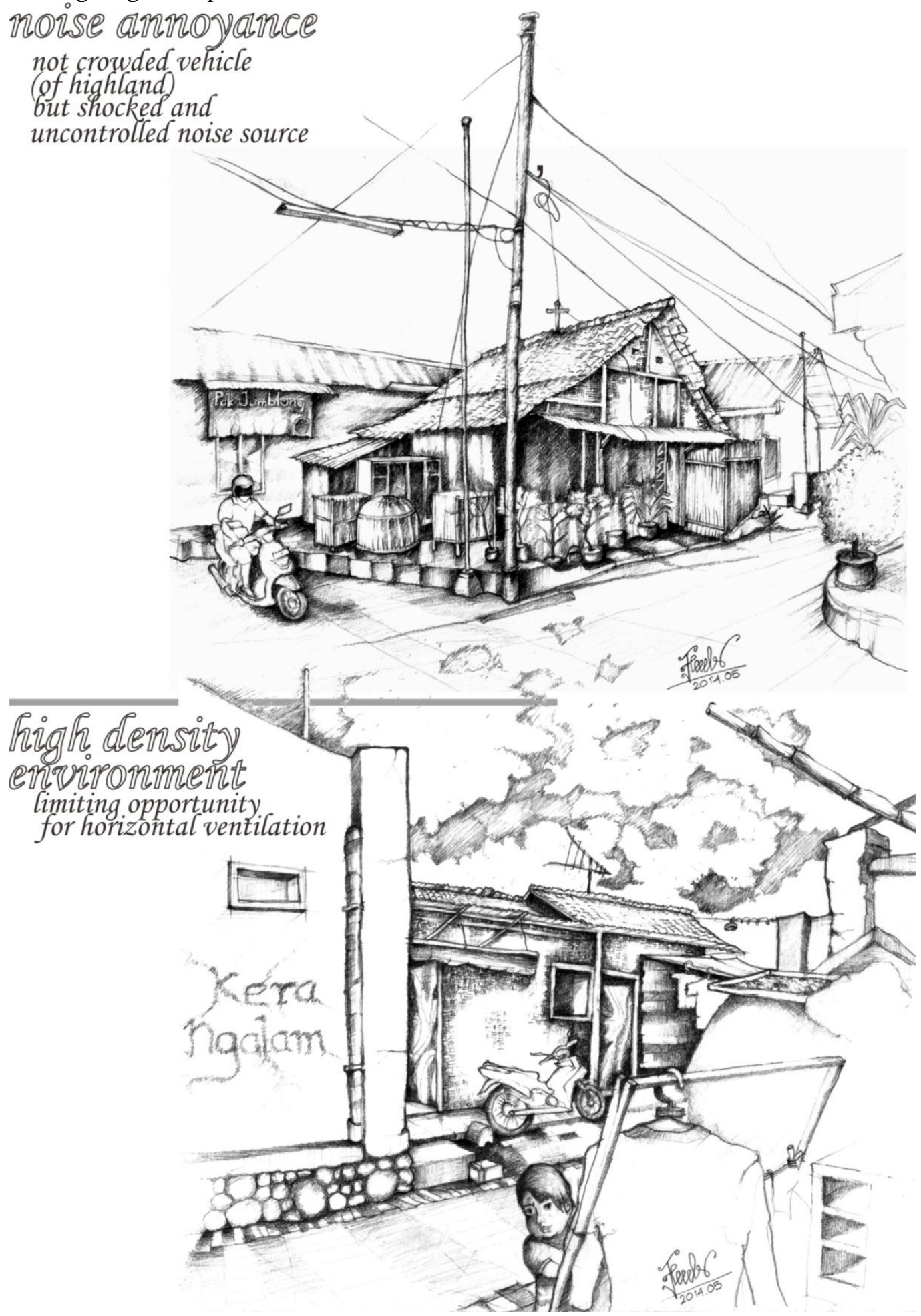

Sumber: Survei Lapangan, Malang (2014) dan Ilustrasi Penulis (2018). 